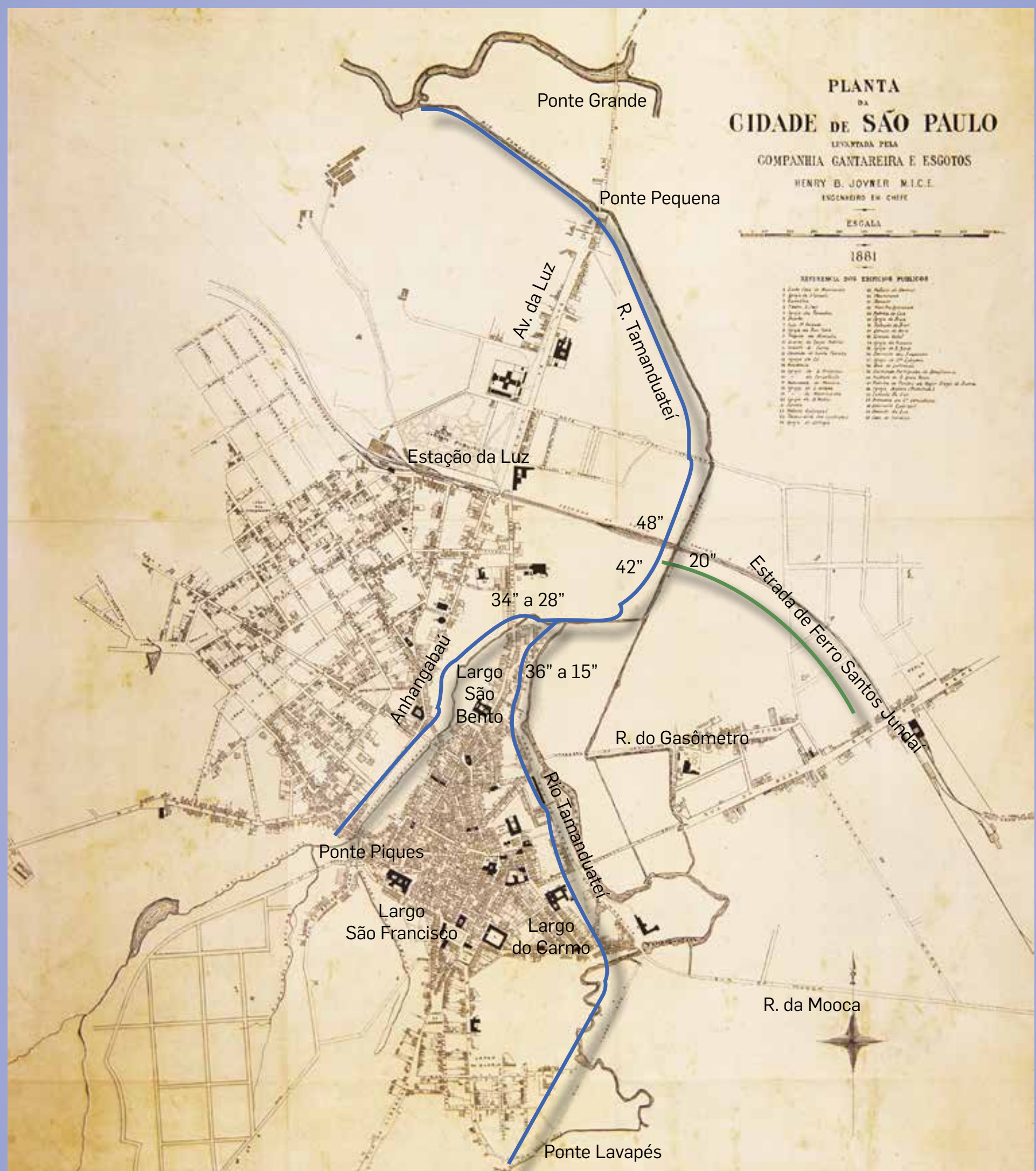

Sistema de coletores de esgotos e emissários na cidade de São Paulo, iniciado em 1886. Fonte: OSEKI, 1992 


\section{Engenheiro \\ João Pedro de Jesus Netto, o patrono do tratamento de esgotos sanitáríos de São Paulo}

DOI 10.4322/dae.2014.135

Américo de Oliveira Sampaio

americosampaio@sabesp.com.br

$\mathrm{O}$ engenheiro João Pedro de Jesus Netto foi o precursor do desenvolvimento das modernas tecnologias de tratamento de esgotos sanitários e de controle de recursos hídricos no Brasil. Grande parte dos numerosos artigos que escreveu foi publicada na revista RAE e constitui um dos legados mais importantes e significativos para a literatura técnica da engenharia sanitária nacional. Seus textos abordam, com objetividade e grande riqueza de detalhes, temas até então pouco conhecidos, evidenciando a preocupação em produzir documentos com forte cunho educativo, que pudessem contribuir para a capacitação de novos profissionais que ingressavam na área de saneamento ambiental.

Iniciada em 1886, com a implantação do sistema de afastamento e encaminhamento para a estação elevatória da Ponte Pequena dos esgotos produzidos nos bairros de Santa Ifigênia, Luz, Liberdade, Bexiga, Brás e Mooca, a coleta do esgoto sanitário produzido na cidade de São Paulo acarretou melhora significativa das condiçóes de saúde da população paulistana, embora pouco ou nada contribuísse para conter o acelerado processo de degradação dos principais corpos de água que cortam a região, entre os quais o Rio Tietê. (OSEKI, 1992).
No início da década de 1930, o agravamento no estado de poluição desses rios motivou o engenheiro João Pedro de Jesus Netto a aprofundar seus conhecimentos sobre os processos de poluição e autodepuração de cursos de água, resultando na produçấo de vários documentos que foram publicados nos principais periódicos da época.

Em dezembro de 1933, o Boletim do Instituto de Engenharia publicou o primeiro documento abordando o assunto em questão (JESUS NETTO, 1933). Nesse artigo, o sanitarista apresenta os resultados de um extenso e minucioso programa de monitoramento da qualidade da água do Rio Tietê, no trecho de cerca de 155 quilômetros, situado entre o município de Guarulhos (montante das descargas de esgoto do bairro da Penha) e a cidade de Itu.

Vale notar que, naquela época, havia discussões em efervescência sobre o avançado estado de degradaçáo do rio, embora ainda não existissem dados significativos e confiáveis sobre as características físico-químicas e microbiológicas de sua água, conforme podemos observar na introduçáo do texto da referida publicação, reproduzida a seguir: 


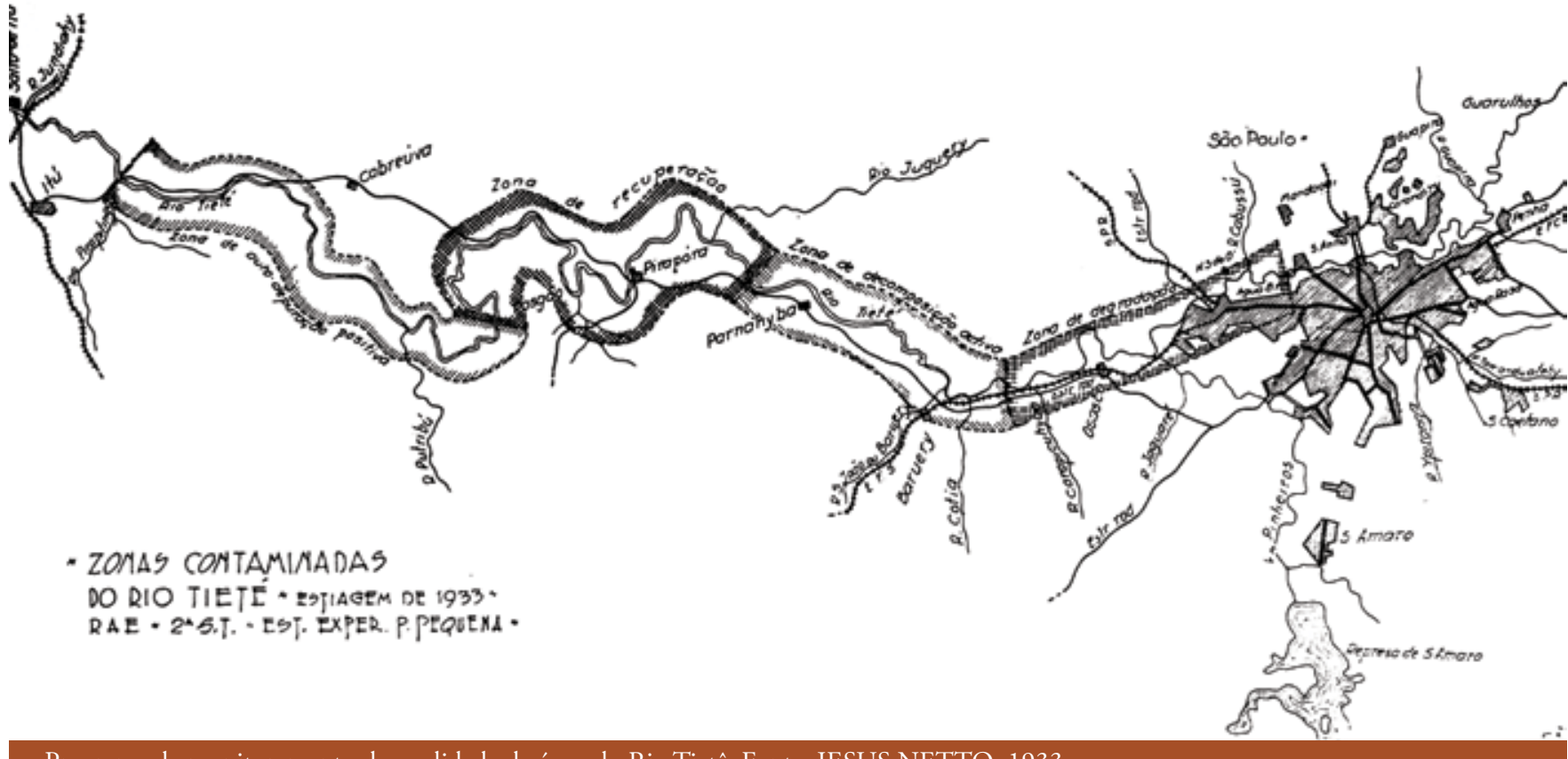

Programa de monitoramento da qualidade da água do Rio Tietê. Fonte: JESUS NETTO, 1933

Muito se tem discorrido sobre a polluição das aguas do rio Tietê pelas descargas "in natura" da totalidade dos esgôtos da cidade de São Paulo. As apreciaçóes sobre a contaminaçáo do rio tem se baseado principalmente em observaçóes sobre o aspecto physico de suas aguas nos pontos das descargas, a relação approximada entre os volumes de esgoto e do rio nas estiagens, e a formação de bancos intercorais, particularmente nas proximidades $\mathrm{da}$ Estação Elevatoria da Ponte Pequena, onde se processa o lançamento do volume total correspondente a contribuição da rêde de esgôtos da vertente direita do rio Tamanduathey. Conquanto esses elementos de observação sejam de incontestavel valor, e perfeitamente convincentes das precarias condicçoes do Tietê, elles não dão uma idéa exacta do estado de polluiçáo do rio, nem uma medida da extensão e do gráo de contaminação a que attingem actualmente as suas aguas. (JESUS NETTO, 1933).

O pioneiro programa de monitoramento, desenvolvido durante uma severa estiagem ocorrida na regiáo da bacia do alto e médio Tietê em 1933, concentrou esforços na determinação analítica dos parâmetros de oxigênio dissolvido e coliformes.

Com relação à concentração de oxigênio dissolvido, os dados obtidos demonstraram valores inferiores ao mínimo necessário para manutenção da vida de peixes no trecho de cerca de 50 quilômetros, situado entre o ponto de confluência com o Rio Pinheiros e as proximidades da cidade de Pirapora.

É interessante destacar que, para avaliar a pertinência de adotar os limites mínimos de oxigênio dissolvido sugeridos na época pela literatura internacional, o ilustre sanitarista desenvolveu bioensaios utilizando espécimes de peixes representativos da fauna local. Tal estudo, realizado no laboratório da estação elevatória da Ponte Pequena, pode ser considerado pioneiro no uso dessa técnica no Brasil. A seguir, transcrevemos um pequeno trecho sobre as principais conclusôes obtidas nesses ensaios:

Há uma certa divergência no que se refere às taxas de oxigênio dissolvido, a adotar como padrão de poluição tolerável. O limite mínimo de oxigênio dissolvido, tolerável em águas recebendo descargas de esgotos, é geralmente fixado entre 4,3 e 5,0 p.p.m. (47\% - 54\% de saturação a $250 \mathrm{C}$ ). Estas taxas, segundo certos higienistas, podem baixar até $25 \%$ de saturação (2,3 p.p.m.), subordinandose porém este mínimo às condiçôes dos depósitos benthais de lodo nos cursos d'agua. A taxa de 2,5 p.p.m. ( $27 \%$ de saturação a 200 C), foi experimentalmente ensaiada na Ponte Pequena para a vida de peixes. Se bem 


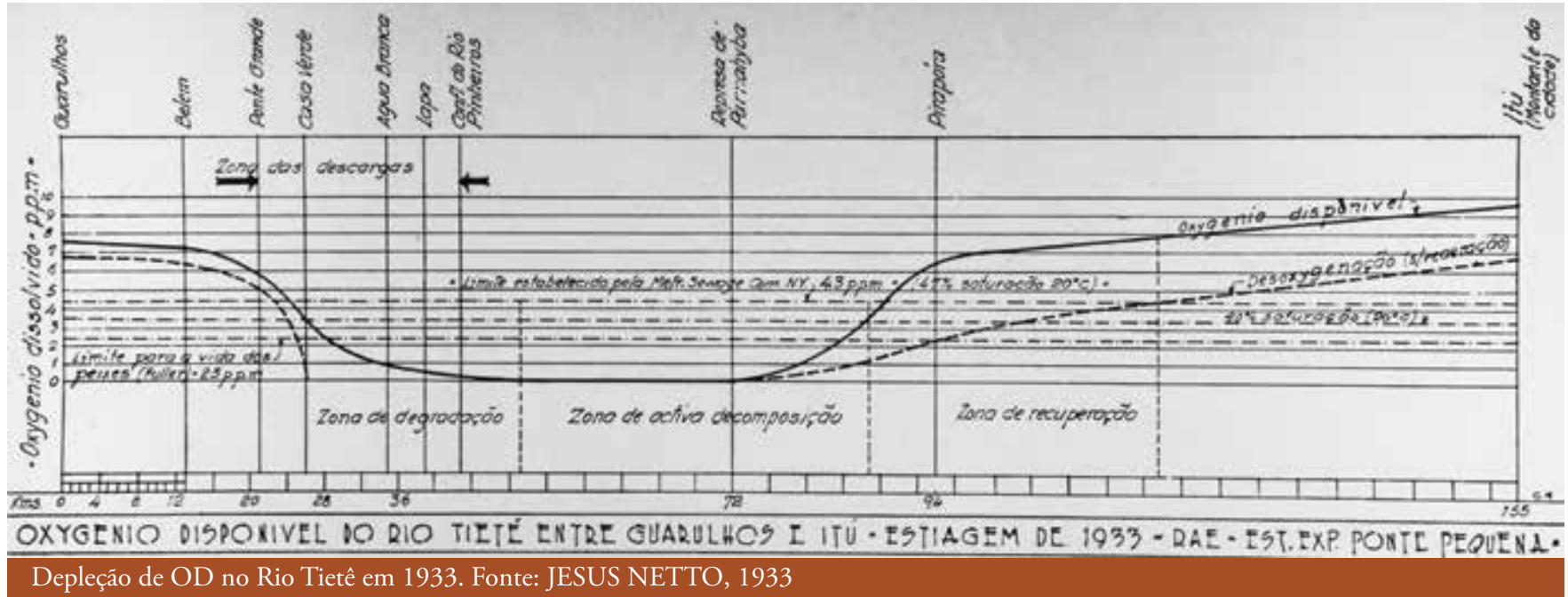

que haja peixes de espécies rústicas, comuns em nossos rios, capazes de subsistir sob tão baixa concentração de oxigênio, é desaconselhável descer, na prática, a esse limite, pois as espécies que sobrevivem têm diminuída a sua resistividade às toxinas, doenças bacterianas, e decaem na sua reprodutividade (JESUS NETTO, 1946).

As análises bacteriológicas empreendidas demonstraram concentraçóes de coliformes totais bastante elevadas em todo o trecho pesquisado, atingindo o valor máximo no ponto situado na represa de Parnaíba. Constata-se igualmente que, em todo trecho avaliado, as características bacteriológicas da água bruta do Rio Tietê não atendiam aos limites mínimos exigidos para abastecimento público, mesmo após tratamento convencional (coagulação, filtração e cloração).

Diante do avançado estágio de degradação da qualidade da água do principal rio da cidade, claramente evidenciado pelos resultados apurados no referido programa de monitoramento, Jesus Netto recomendou enfaticamente a im-

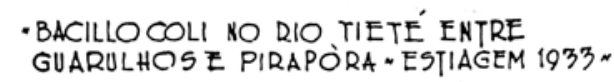

- RA.E. * 2*S.T.

- EST. eXPER, da P. PEQUENA.

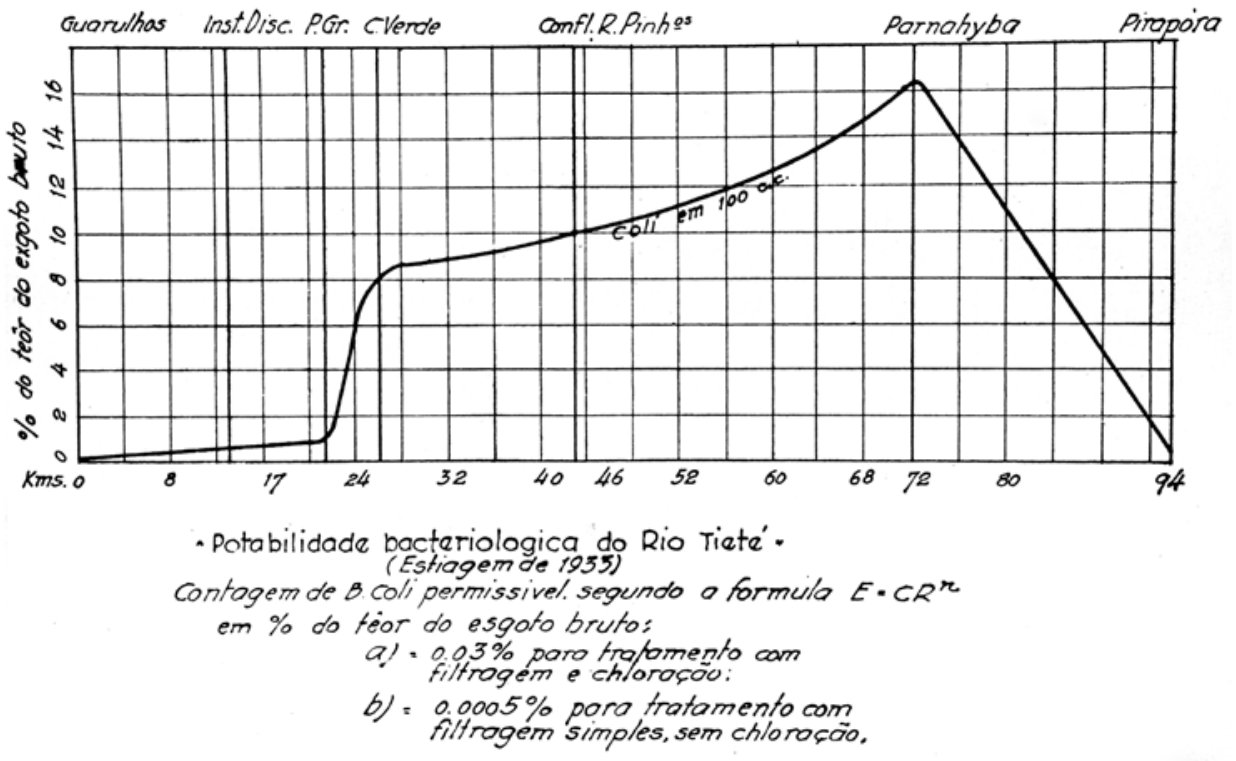

Valores da concentraçáo coliformes no Rio Tietê. Fonte: JESUS NETTO, 1933 
plantação de um programa governamental para promover o tratamento dos esgotos domésticos produzidos na cidade de São Paulo.

As investigações da Estação de Ponte Pequena, synthetisadas nesta ligeira exposição, mostram á evidencia que o Rio Tietê em aguas minimas, poluido pelos esgôtos da cidade, representa um constante perigo de infecção aos ribeirinhos entre São Paulo e Pirapora numa extensão de 73 kilometros, pelo leito do rio. Exhausto de oxygenio, carregado de materia organica em decomposição, povôado de germens e despovôado de peixes, - vae o lendario rio paulista arrastando pelo seu leito, desde a Capital até as cercanias de Itú, aguas improprias para os mistéres da vida. Urge o tratamento dos esgôtos de Sáo Paulo para liberta-lo dos perigosos elementos de polluição que elle carrega em seu bôjo ; e como complemento, é indispensavel o reajustamento das condicçôes sanitarias dos seus dois affluentes - o Pinheiros e o Tamanduatehy. (JESUS NETTO, 1933).

Durante a década de 1930, Jesus Netto publicou ainda outros quatro artigos sobre esse tema (JESUS NETTO, 1935, 1938 e 1939), nos quais abordou mais detalhadamente a base conceitual e metodológica da modelagem dos processos biogeoquímicos responsáveis pela poluição e autodepuração de cursos de água.

Inconformado com o avançado estado de degradação das águas dos principais rios da Regiáo Metropolitana de São Paulo e procurando encontrar soluçóes efetivas para esse grave problema, Jesus Netto iniciou aquela que poderíamos chamar de segunda e mais importante fase de sua vida profissional: a elaboração de projetos, construção e operação de estaçóes de tratamento de esgotos.

Antes de apresentar as contribuiçóes do engenheiro no campo de tratamento de águas residuárias, cabe tecer alguns breves comentários sobre a precariedade da infraestrutura de esgotamento sanitário existente à época.

Apesar do vertiginoso crescimento populacional nos grandes centros urbanos do Estado de São Paulo, observado a partir do início do século XX, havia poucas iniciativas concretas no sentido de provê-los de eficientes sistemas de es- gotamentos sanitários, particularmente os relacionados ao tratamento dos efluentes produzidos. A maioria das açóes esporádicas empreendidas para a resoluçáo de problemas específicos empregava operações físicas de decantação primária, complementadas ou não por processos biológicos anaeróbicos (tanques sépticos). Tais instalações tinham utilização restrita à solução de tratamento de esgotos de pequenas comunidades (não superiores a 10 mil habitantes), não constituindo, portanto, soluçóes passíveis de serem adotadas para grandes aglomerados urbanos como a cidade de São Paulo, cuja população, nas primeiras décadas do século XX, já ultrapassava 500 mil habitantes.

Vale ainda ressaltar que, até o final do século XIX, mesmo nos países desenvolvidos da Europa e América do Norte, as tecnologias utilizadas para o tratamento de águas residuárias se limitavam à disposição contínua ou intermitente em solos agrícolas ou em filtros percoladores de areia, cascalho ou pedras. Embora muito mais eficientes e compactas quando comparadas às tecnologias de tratamento anaeróbico, essas novas instalaçóes ainda apresentavam limitaçóes que dificultavam seu emprego de forma mais generalizada. Somente na segunda década do século XX, um novo e revolucionário processo de tratamento - o de Lodos Ativados, desenvolvido por pesquisadores ingleses e americanos - teve sua base conceitual e metodológica anunciada. Por apresentar vantagens consideráveis quando comparados às técnicas até então existentes, essa nova tecnologia passou a ser rapidamente empregada no tratamento dos esgotos produzidos nas grandes cidades da Europa e da América do Norte.

Cumpre ainda salientar que, no início do século XX, o pensamento positivista tinha grande influência na definição das políticas públicas adotadas no Brasil, particularmente as relacionadas à engenharia sanitária, que tinha em Saturnino de Brito (1864 - 1929) seu maior e mais ilustre representante. Apesar do grande avanço da microbiologia promovido pelos trabalhos de Anton van Leeuwenhoek (1632-1723), Lazzaro Spallanzani (1729-1799), Louis Pasteur (1822-1895) e Robert Koch (1843-1910), entre outros, os positivistas ainda relutavam em aceitar o emprego dos conhecimentos dessa nova ciência para a resoluçáo dos problemas enfrentados na época. Saturnino de Brito, fervoroso positivista, manifestou contrariedade em relaçáo ao uso de técnicas biológicas de tratamento de esgoto, em 
particular a dos Lodos Ativados, posição só alterada no final de sua vida (BRITO, 1926).

É nesse contexto que João Pedro de Jesus Netto inicia os trabalhos pioneiros em busca da reversão do já adiantado estágio de degradação da qualidade da água dos principais rios da cidade.

Segundo o sanitarista José Martiniano de Azevedo Netto (1918-1991), que trabalhou com Jesus Netto durante alguns anos na RAE - Repartição de Águas e Esgotos do Estado de Sáo Paulo, na década de 1930, o engenheiro convenceu a diretoria da RAE a aprovar o projeto e construçáo da primeira estação experimental de tratamento de esgotos da Ponte Pequena (AZEVEDO NETTO, 1986).

O projeto experimental previa diferentes tipos de operações e processos de tratamento. Em 1933, suas instalaçóes foram executadas em uma pequena parcela do terreno desapropriado para a construção da estação elevatória de esgotos da Ponte Pequena, localizado às margens do Rio Tamanduateí, próximo à confluência com o Rio Tietê.

No início, foram construídos tanques sépticos, filtros biológicos percoladores e tanques de diluição, ou fishponds. Nesses últimos foram realizados os primeiros bioensaios anteriormente citados, nos quais, através de sucessivas diluiçóes

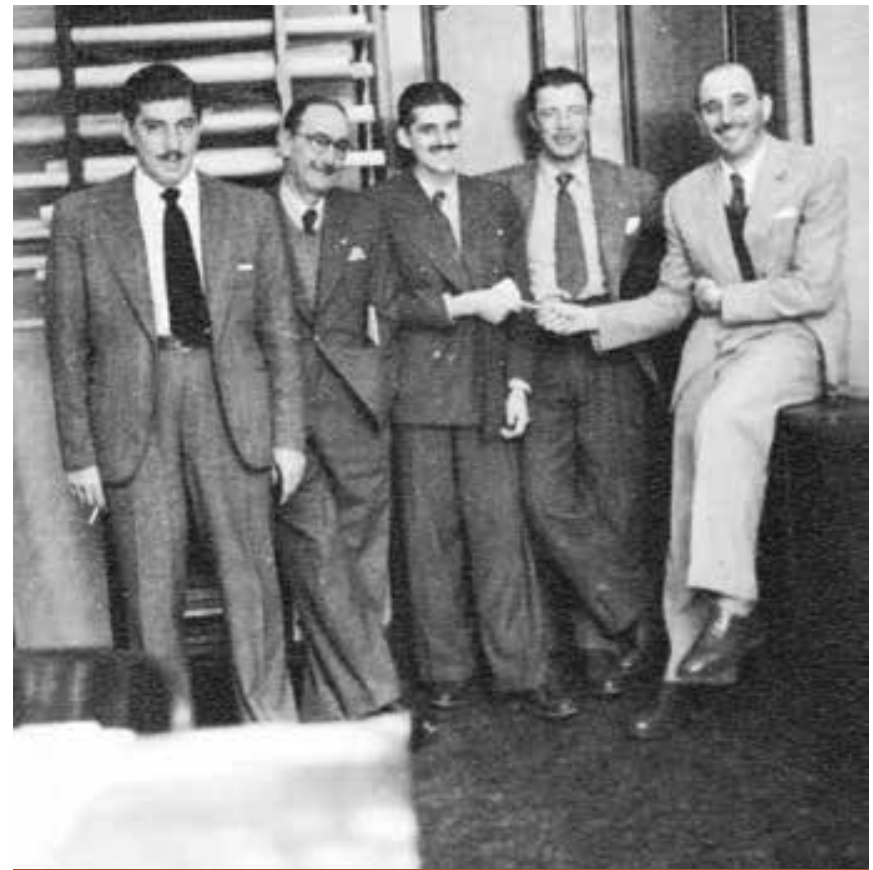

Engenheiros da R.A.E - Repartiçáo de Aguas e Esgotos do Estado de Sáo Paulo: Engo João Pedro de Jesus Netto, o segundo da esquerda para a direita; José Martiniano de Azevedo Netto, ao centro

do esgoto bruto coletado da elevatória, foram avaliadas as concentraçóes mínimas de oxigênio dissolvido que deveriam ser mantidas no corpo de água receptor, de modo a preservar a vida de espécimes de peixes representativos da fauna local.

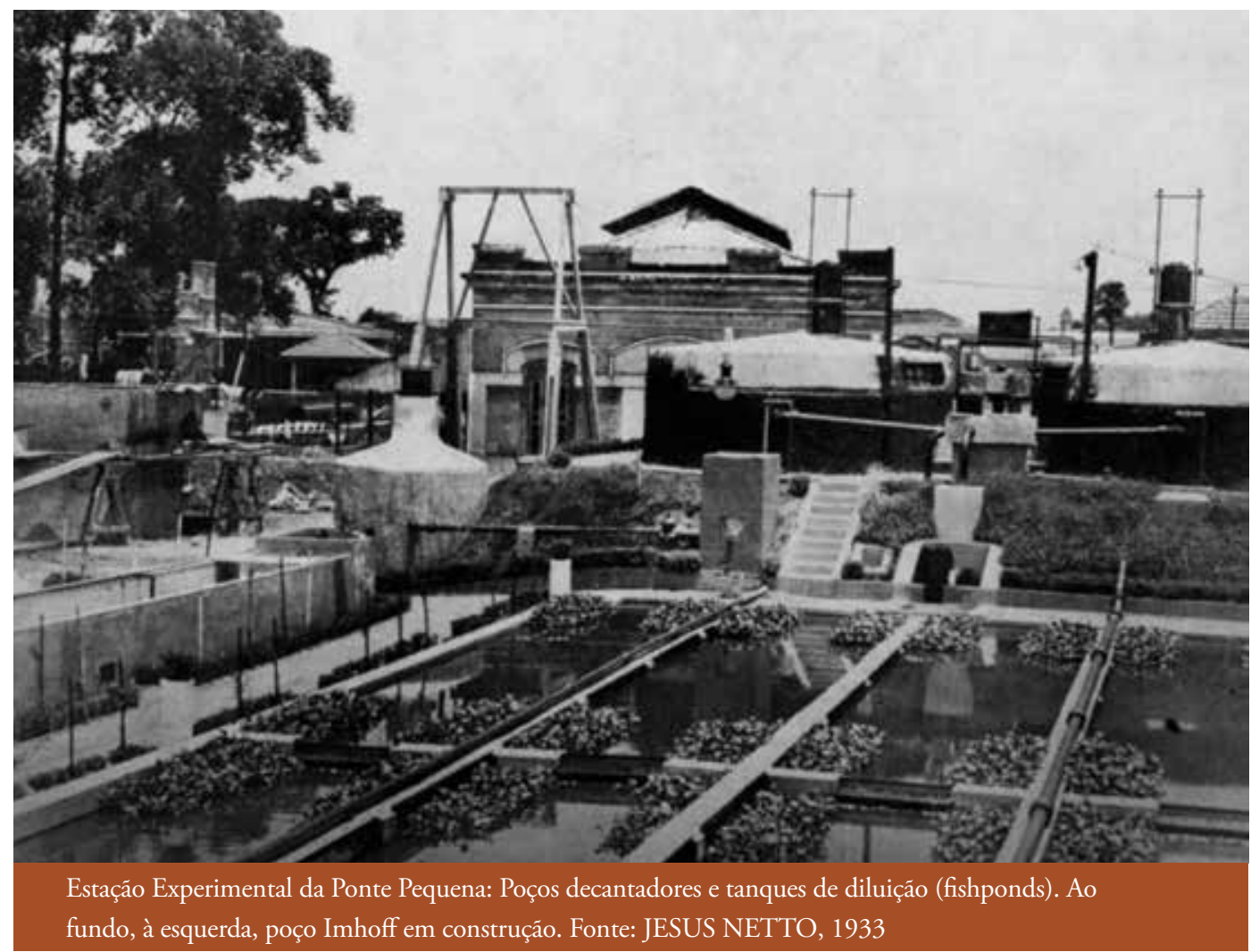




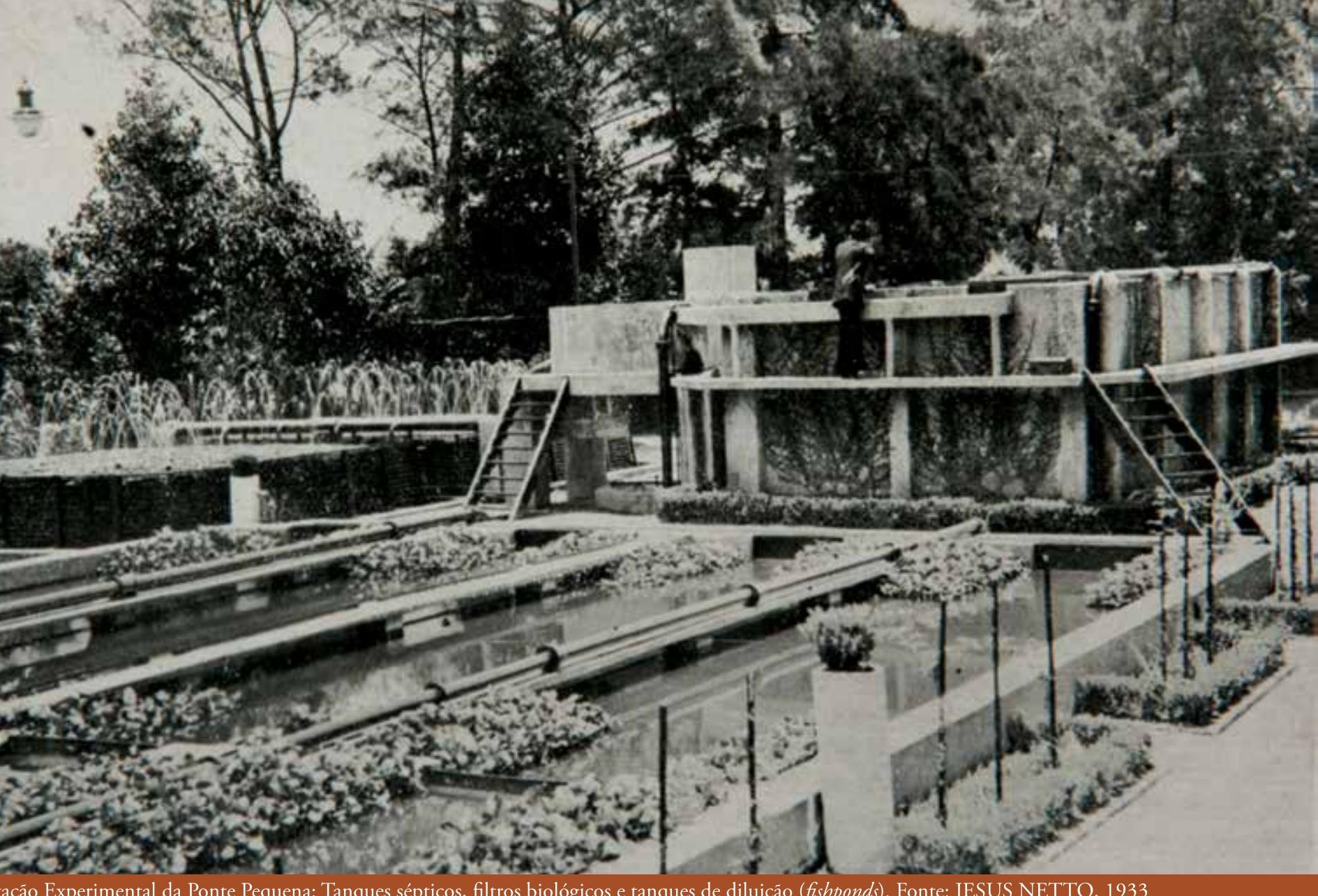

Estação Experimental da Ponte Pequena: Tanques sépticos, filtros biológicos e tanques de diluição (fishponds). Fonte: JESUS NETTO, 1933

Laboratório da Estação Experimental de Ponte Pequena. Fonte: JESUS NETTO, 1933

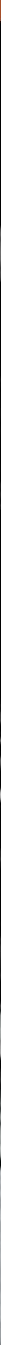


Ainda nessa primeira fase de execução, a instalação ganhou um moderno laboratório, com capacidade de realizar determinaçóes analíticas dos principais parâmetros utilizados para a avaliação operacional de instalaçóes de tratamento de esgotos e dos processos de poluiçáa e autodepuração de corpos de água.

Em um segundo momento, a estação experimental foi complementada com a implantação de mais duas instalaçóes de depuração: Tanques Imhoff (uma versão melhorada das já tradicionais fossas sépticas) e o revolucionário processo de "lodos ativados", até então inédito em terras sul-americanas.

Nessa segunda etapa do empreendimento, foi também construído um engenhoso e moderno sistema de coleta e utilização dos gases produzidos nas unidades de tratamento anaeróbico. Inicialmente os gases eram sugados diretamente do poço decantador e utilizados, sem qualquer tratamento prévio, para operação de um motor de 1 1/2 HP. O aumento na produção de gases resultantes da execução dos tanques sépticos e Imhoff possibilitou a operação de uma usina geradora termoelétrica com capacidade de geração de 120,7 quilowatts/h, que produzia energia para diversos usos da estação experimental, incluindo o funcionamento dos compressores de ar dos tanques de lodos ativados.

Informações pormenorizadas sobre essa importante instalação de aproveitamento energético de biogás podem ser obtidas em JESUS NETTO, 1935; 1936.

Indubitavelmente, a estação experimental da Ponte Pequena representou um dos principais marcos do tratamento de esgotos não só do Estado de São Paulo, mas também de todo o Brasil. Seu projeto arrojado e inovador e o alto nível das pesquisas nela desenvolvidas possibilitaram significativo avanço no conhecimento técnico da engenharia sanitária nacional.

O grande interesse que a instalação despertou junto à opinião pública fica claramente evidenciado em duas reportagens publicadas em $1^{\circ}$ e 8 de novembro de 1934 no jornal Correio de São Paulo, um ano após sua inauguração. Tais reportagens, cujos trechos seguem transcritos, foram realizadas após visita guiada pelo próprio Jesus Netto à estação.

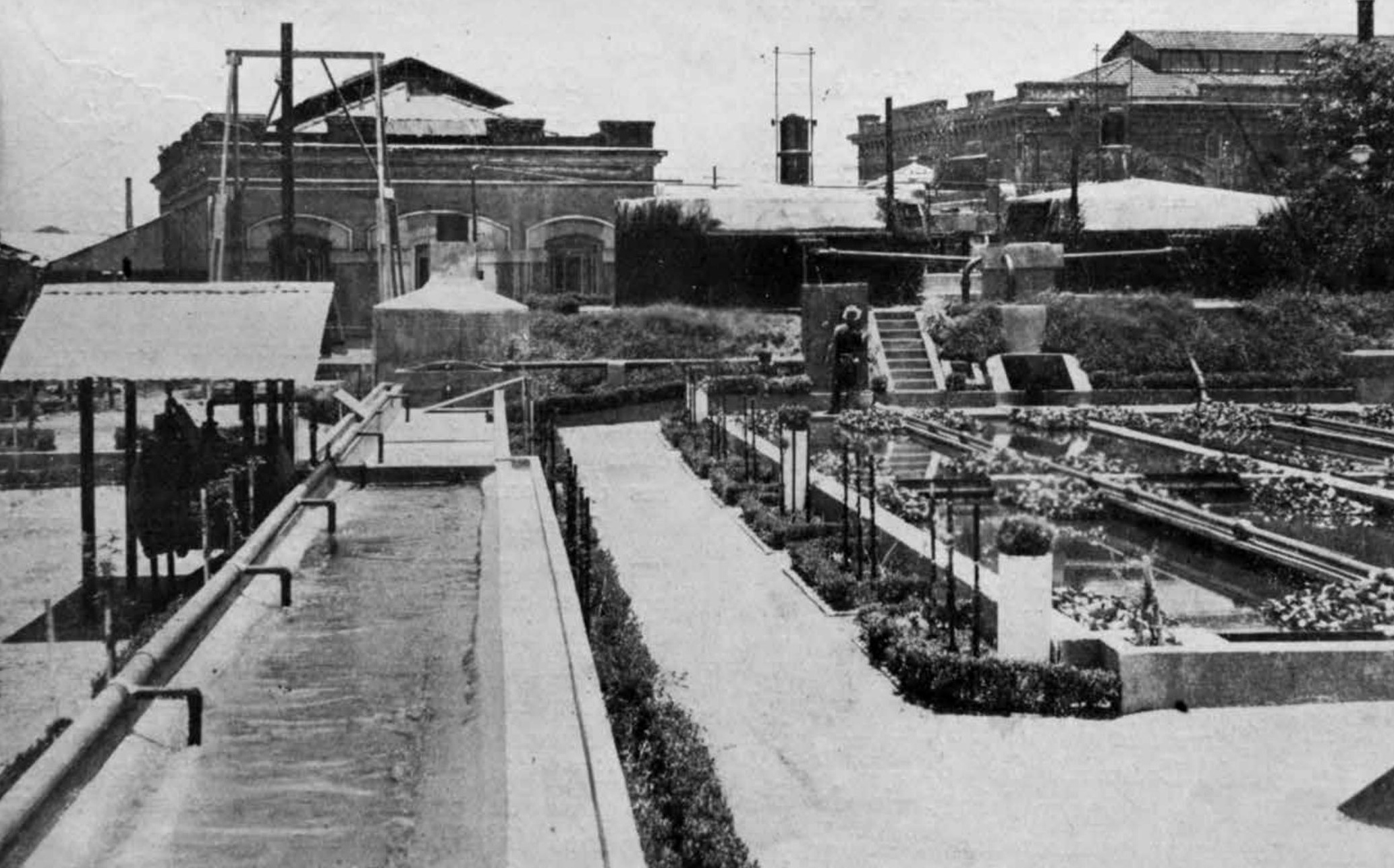


Dentro da capital paulista, actualmente, effectua-se uma interessante actividade experimental, sob direcção da Segunda Secção Technica da Repartição de Aguas e Esgotos da Secretaria da Viação, a respeito de purificação de esgotos. A razão por que se processam esses estudos, que tem seu campo ao lado da Usina Elevatória de Ponte Pequena, prende-se ao seguinte: Como a única válvula que foi utilizada para esse mister - o rio Tietê - no correr dos annos transformou-se numa verdadeira cloaca que, sem duvida, é um constante perigo á salubridade publica. De mais a mais, todos o animaes que vivem dentro do nosso maior curso de agua, estão por essa forma condemnados ao desapparecimento. Mas, o que precisa ficar patente é que esses trabalhos se realizam pela primeira vez na América do Sul. A cidade exige a applicação de um systema de decantação para os esgotos, effectuando-se as experiências com differentes processos, para que se verifique qual deles é o mais adaptável ás condiçóes de nossa metrópole [...] Uma visita ao campo experimental de Ponte Pequena, como a que realizou um repórter do "Correio de $S$. Paulo", apresenta uma série de interessantes surpresas da technica e da sciencia. Conforme dissemos, o redactor do “Correio de S.Paulo" percorreu as dependências da estação de estudos na companhia do dr. J.P. Jesus Netto, pertencente á secção da Secretaria de Viação, dirigida pelo dr. Hippólito da Silva. Com esse engenheiro é que fomos obtendo esclarecimentos do complexo apparelhamento com que topavamos, chamando-nos o dintincto technico desde o início para o local onde se "fabricava", nada mais nada menos, gaz de iluminação com os esgotos de São Paulo. (CORREIO DE S.PAULO, 1934).

Não obstante sua importância histórica e seu enorme legado teórico e prático para a engenharia sanitária brasileira, a estação de tratamento de esgotos da Ponte Pequena lamentavelmente foi demolida no final dos anos 1930. Os poucos registros hoje disponíveis encontram-se em textos, desenhos e fotografias dos artigos publicados por Jesus Netto.

A partir da experiência acumulada no campo experimental da Ponte Pequena e devido à escassez de área disponível nesse local para ampliação das instalações, o engenheiro iniciou seu projeto mais importante e ambicioso: a estação de tratamento de esgoto do Ipiranga.

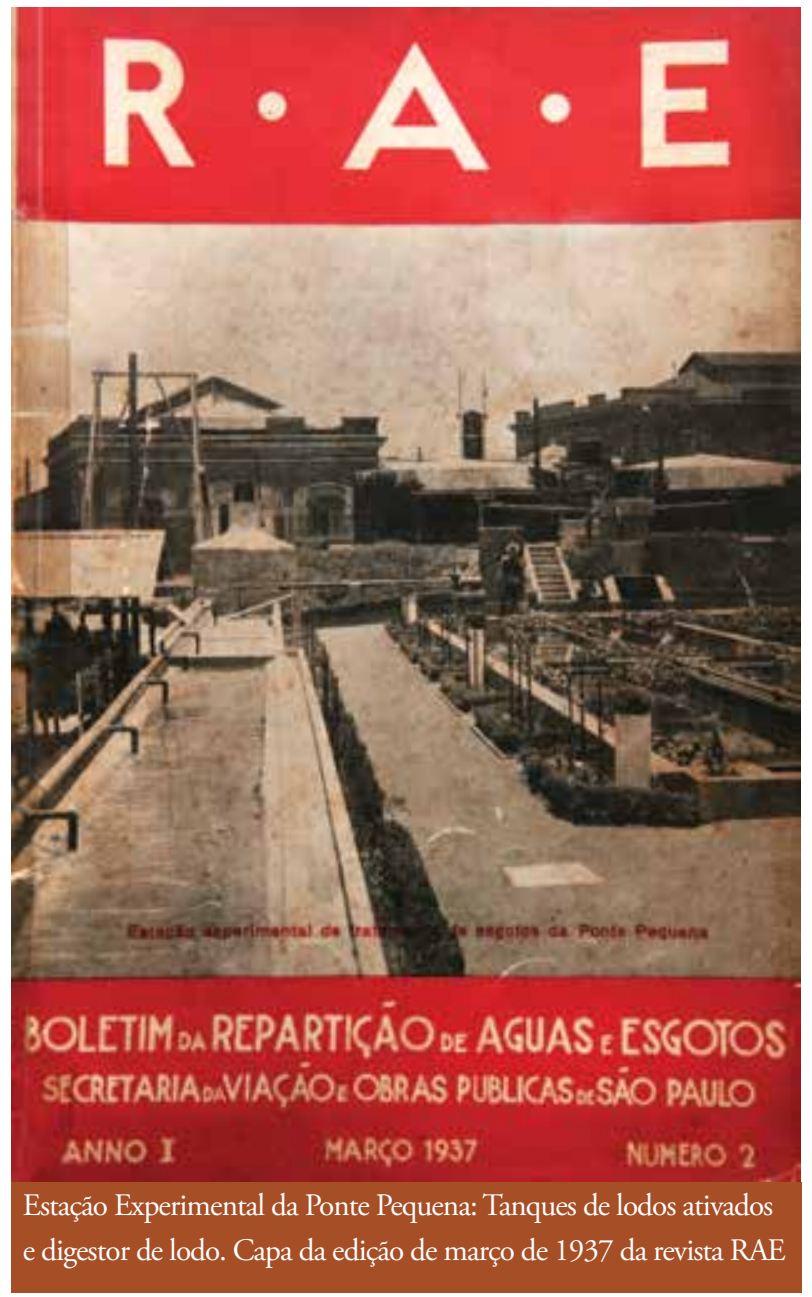

O aumento populacional ocorrido na década de 1930, nos bairros situados na zona baixa de drenagem do Rio Tamanduateí, não acompanhado pela implantação de sistema de esgotamento sanitário, acarretou aumento considerável das taxas de morbimortalidade relacionadas a doenças de veiculação hídrica nessa região, o que obrigou a Repartição de Água de Esgotos (RAE) a tomar providências urgentes para seu equacionamento.

O afastamento dos esgotos coletados dependia, porém, da construção de um prolongamento de $2,5 \mathrm{~km}$ do emissário da margem esquerda do Tamanduateí. No entanto, além de onerosa, essa obra estava sujeita a problemas urbanísticos ainda não resolvidos, como o da retificaçáo do rio.

$\mathrm{Na}$ impossibilidade de encontrar uma solução rápida para o problema, a Segunda Seção Técnica da RAE optou pela construção de uma instalação para promover o tratamento dos esgotos produzidos no bairro do Ipiranga. 


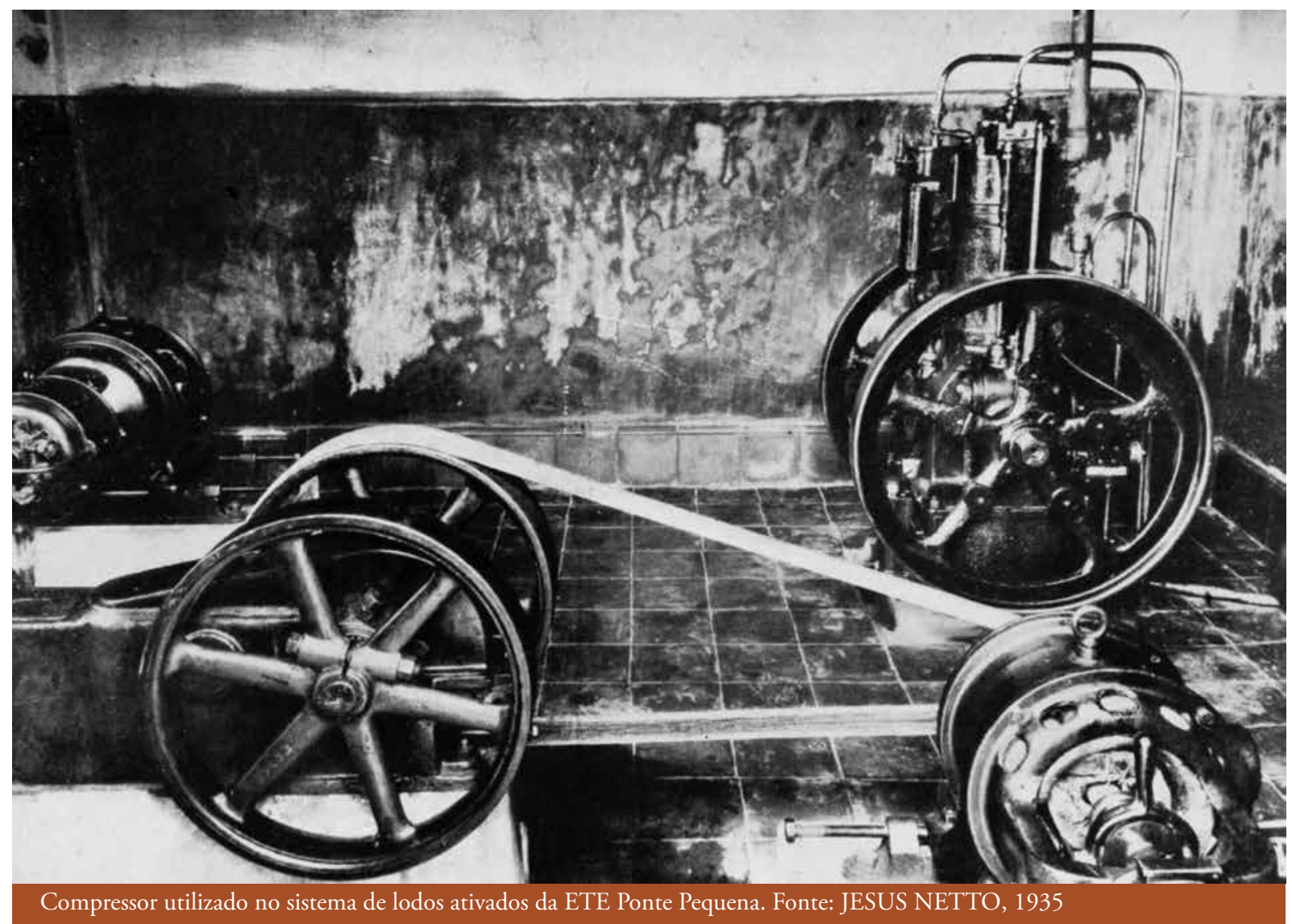

Jesus Netto aproveitou essa oportunidade para dar continuidade aos estudos e experimentos até então conduzidos na estação experimental da Ponte Pequena. Em artigo publicado na revista RAE, parte do qual transcrito a seguir, ele manifestou claramente essa intenção:

A solução adoptada, como é fácil de ver, attinge dois fins, ambos utilíssimos: promove o saneamento immediato do districto em questão, e abre um campo mais vasto e mais completo, para prosseguimento e confirmação das complexas investigaçóes levadas a effeito na experimental da Ponte Pequena, durante cerca de quatro annos.

Se bem que não tenhamos duvidas acerca dos resultados á obter no Ypiranga, dada a já relativa facilidade de ambientação dos nossos problemas de esgotos, depois dos actuaes conhecimentos da 2.a S.T. no campo experimental, ter-se-há contudo uma excellente opportunidade para observaçóes, não só sobre os effeitos de certos dispositivos destinados a aumentar a efficiencia dos apparelhamentos de tratamento, como também sobre a efficacia dos systemas e processos de depuração mais em destaque na moderna technica sanitária, com inclusão do aproveitamento de sub-productos resultantes dos processos adoptados. (JESUS NETTO, 1937).
O tipo e grau de tratamento da estação foram definidos com base em estudos desenvolvidos por Jesus Netto, que levavam em consideração a taxa de diluição e a capacidade de autodepuração do Rio Tamanduateí, processo este cuja base teórica foi intensamente investigada durante sua primeira fase profissional.

Sendo um rio de planície, com baixa velocidade de escoamento e já recebendo, à montante do bairro de Ipiranga, contribuição "in natura" dos esgotos da cidade de Sáo Bernardo do Campo, adotou-se uma concepção de projeto de estação visando alta eficiência na remoção de carga orgânica, de modo a possibilitar a manutenção de níveis de concentraçôes de oxigênio dissolvidos nas águas desse rio que fossem compatíveis com os exigidos para a preservação da vida aquática.

Embora o processo de lodos ativados tenha sido testado para o tratamento de esgotos na estação experimental da Ponte Pequena e gerado resultados excelentes, o tipo de tratamento inicialmente escolhido para a nova instalação foi o de "Ciclo Completo", nomenclatura utilizada, na época, para definir instalações depuradoras que utilizassem conjuntamente as seguintes operaçóes unitárias: gradeamento, caixas de areia, sedimentação primária de sólidos em suspensão, sedimentação de sólidos coloidais por ope- 
raçóes físico-químicas (coagulação/floculação e sedimentação final), digestão do lodo e desinfecção do efluente final. (JESUS NETTO, 1937).

É provável que as operações de tratamento físico-químico utilizadas na primeira etapa de construção da estação do Ipiranga estejam relacionadas às desconfianças então reinantes dos sanitaristas brasileiros acerca da aplicabilidade de processos biológicos aeróbicos para depuração de esgotos sanitários. Jesus Netto certamente não compartilhava as mesmas desconfianças de seus colegas de profissão, como se pode observar em seu artigo sobre o projeto da estação, publicado em 1937.

Predomina ainda, na solução de nossos problemas sanitários, a extranha subordinação de um exagerado senso de economia, sobre as soluções justas e adequadas. Essa situação é ainda aggravada por uma certa dose de incredulidade dos technicos que, ao envez de investigar o assunto em seus detalhes, regeitam "a priori”"os methodos ensaiados no extrangeiro, e de algum modo - sem a menor base, aliás -, da eficiencia de certos dispositivos, tendentes a melhorar e facilitar os trabalhos das instalaçóes de tratamento." ( JESUS NETTO, 1937).

No final de 1941, cinco anos após sua inauguração, a estação foi complementada com o sistema de "lodos ativados". Há descrições detalhadas das diversas unidades, assim como dos procedimentos adotados na partida dessa nova instalação,no artigo publicado na revista (JESUS NETTO, 1942). No referido artigo, o autor demonstra o quanto estava a par do que havia de mais avançado no arcabouço teórico e prático então existente em relação a esse inovador processo de tratamento. A abordagem, minuciosa e didática, com que descreve os principais mecanismos responsáveis pela degradação e sedimentação biológica do processo de lodos ativados, demonstra a preocupação constante do engenheiro em contribuir para a capacitação de profissionais que estavam ingressando nesse ramo de atividade.

A intenção de utilizar a estação de tratamento do Ipiranga, não apenas para promover o adequado tratamento de esgoto desse bairro, mas principalmente como uma verdadeira "escola” para capacitar novas geraçóes de engenheiros sanitaristas responsáveis pela execução e operação dos futuros sistemas de tratamento de águas residuárias do Estado de
São Paulo, foi também manifestada em artigo publicado em 1937, reproduzido parcialmente a seguir.

Procurando embora projectar e construir a estação do Ypiranga nos moldes da moderna technica do tratamento dos esgotos a $2^{a}$ S.T. não pretende, como já esclareceu, ater-se apenas ao platonico controle do seu funccionamento. Os progressos da depuração dos liquidos de esgotos e dos lodos resultantes da depuração, têm sido por demais vertiginosos para que o engenheiro se detenha e se fixe no ambito limitado do simples funccionamento de sua installação de tratamento. Elle precisa observar, raciocinar e deduzir, lançando mão da experimentação que lhe fornecerá os elementos precisos, não só para o ajustamento technico e econômico da sua propria installaçáo, como para manter-se dentro dos progressos que dia a dia vêm enriquecendo o campo vasto e complexo dos problemas de esgotos. (JESUS NETTO, 1937)

A complementação da estação de tratamento do Ipiranga com o processo de lodos ativados foi realizada durante a Segunda Guerra Mundial, quando era praticamente impossível importar equipamentos eletromecânicos indispensáveis para uma instalação desse tipo. Por outro lado, a indústria brasileira ainda não estava suficientemente desenvolvida para sua produção. Surge então, em cena, o espírito empreendedor e pragmático de Jesus Netto que, ciente da enorme importância do empreendimento, procurou insistentemente alternativas para sua viabilização, conforme relatou seu discípulo, o engenheiro Armando Fonzari Pera (1917 - 2007) (BOTELHO, 2000):

[Ele] detestava a burocracia, não concordando com a demora das decisóes, próprias dos processamentos oficiais. Por isso procurou trabalhar com peças recuperadas, ou fruto de sobras existentes nos almoxarifados da RAE na Ponte Pequena que, diga-se de passagem, eram depositários de maravilhas, independendo assim de recursos e burocracia. Desse depositário sempre havia motores, bombas, manômetros, peças especiais, tubulações.

O gasômetro da ETE Ipiranga foi feito com tubos de diâmetro 2,50 m usados nos sifôes da Adutora de Rio Claro. Uma vez fui com ele ao almoxarifado da Ponte Peque- 
na, um imenso galpão sob a responsabilidade do senhor Avelino, que conhecia o depósito e ajudava na procura das coisas. Como prova da descoberta das maravilhas, os tanques de aeração dessa ETE estavam prontos, aguardando os compressores para aeração. Encontramos ainda, engradados, dois maravilhosos compressores IR-30 - LS (Ingersoll Rand) que foram então usados na estação, e que penso ainda devem estar em operação, pois os IR 30 de baixa rotação são eternos. (BOTELHO, 2000)

Conforme citado anteriormente, a utilização dos subprodutos do processo de tratamento era quase uma obsessão para Jesus Netto. Para ele, era inconcebível projetar uma estação desprovida de instalaçóes que permitissem o uso do biogás e do lodo produzidos nos processos e operaçóes da fase sólida do tratamento. Sendo assim, a estação de tratamento do Ipiranga contou, desde o início de sua operação, com sistemas inovadores destinados aos aproveitamentos energéticos do gás e do lodo, como fertilizante.

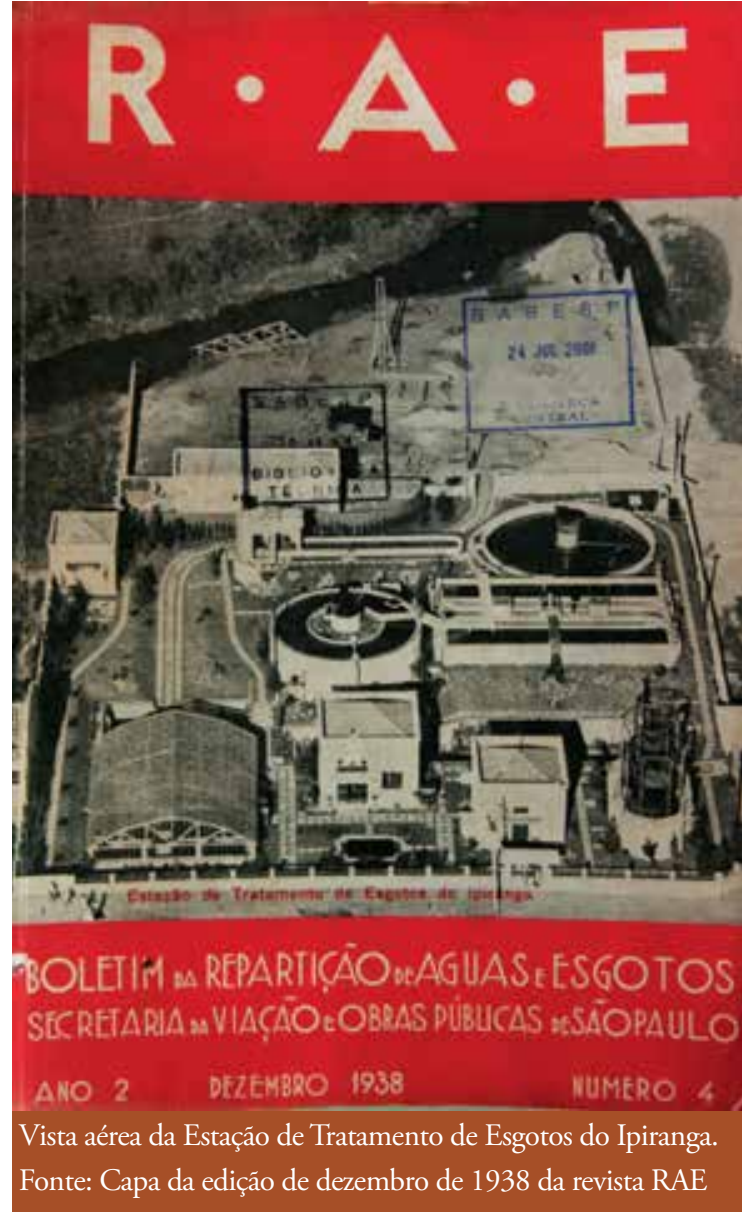

Tais aproveitamentos, cuja aplicabilidade já fora testada anteriormente na estaçáo experimental da Ponte Pequena, despertaram grande interesse e expectativa por parte dos meios de comunicação de massa da época, conforme pode ser constatado nas duas reportagens publicadas no jornal “O Estado de S. Paulo" (MACHADO, 1954).

João Pedro de Jesus Netto faleceu em 26 de julho de 1955, três anos após sua aposentadoria na Repartição de Águas e Esgotos do Estado do São Paulo.

Em 1957, Jânio Quadros, então governador do Estado de Sáo Paulo, reconhece o engenheiro Jesus Netto como "um dos mais ilustres técnicos que trabalharam para o Estado e, em particular, para a antiga Repartição de Águas e Esgotos de São Paulo", e promulga a alteração do nome da ETE Experimental de Tratamento de Esgotos do Ipiranga para Estação Experimental de Tratamento de Esgotos Eng. Joáo Pedro de Jesus Netto através do Decreto Estadual no 28.656 de 12/6/57.

\section{Estação Experimental de Tratamento de Esgotos Eng. João Pedro de Jesus Netto}

JANIO QUADROS, GOVERNADOR DO ESTADO DE SĀO PAULO, usando de suas atribuiçōes legais $\mathrm{e}$

Considerando que o Eng. João Pedro de Jesus Netto, falecido $\mathrm{em} 26$ de julho de 1955 . foi $\mathrm{em}$ vida um dos mais ilustres técnicos que trabalharam para o Estado, e, em particular, para a antiga Repartição de Águas e Esgotos de Sĩo Paulo, à qual serviu até 30 de março de 1951, quando foi aposentado:

Considerando que entre as obras de ine gável utilidade pública concebidas pelo aludido Engenheiro se conta o projeto da Estação Experimental de Tratamento de Esgotos do Ipiranga, nesta Capital, por êle elaborado em 1935;

Considerando que o valor dessa obra, permanente pela sua natureza, têm a realçá-lo o fato de haver sido ela planejada e realizada numa ́poca em que os conheciment a matéria eram muito limitados. mesmo nos países mais adiantados do mundo;

Considerando que a referida unidade se tem constituído $\mathrm{cm}$ escola para várias gerações de engenheiros de Sảo Paulo e do Brasil;

Considerando que o entusiasmo, a dedicação e o pioneirismo daquele Mestre valorizaram o trabalho de várias Comissōes, das quais participou, e proporcionaram inestimável contribuiçẫo a diversos Municípios do Interior, com cujas Prefeituras colaborou;
Decreto No 28.656, de 12/6/57 dá denominação Estação Experimental de Tratamento de Esgotos do Ipiranga, do Departamento de Águas e Esgotos.

Considerando o mérito de seus trabahos, especialmente no momento atual, em que o Govêrno do Estado se empenha na execução de um conjunto de obras sanitárias destinado a ombrear-se com o que de melhor e mais avançado existe no mundo.

\section{Decreta :}

Artigo 1.0 - A Estaçâo Experimental de Tratamento de Esgotos do Ipiranga, nesta Capital, do Departamento de Águas e Esgotos, passa a se denominar "Estação Experimental de Tratamento de Esgotos Eng. João Pedro de Jesus Netto".

Artigo $20^{\circ}-0$ presente Decreto entrará em vigor na data de sua publicaçấo.

Artigo $3 .^{\circ}-$ Revogam-se as disposições em contrário.

Palácio do Govêrno do Estado de São Paulo, aos 12 dias de junho de 1957.

(a) JANIO QUADROS

(a) José Vicente de Faria Lima

Publicado na Diretoria Geral da Secretaria de Estado dos Negócios 'do Govêrno, em 12 de junho de 1957 .

(a) Carlos de Albuquerque Seiffarth Diretor Geral 
Mesmo não fazendo parte das atribuiçóes específicas da Repartição de Águas e Esgotos do Estado de São Paulo, Jesus Netto desenvolveu trabalhos relacionados ao projeto e operação de estaçóes de tratamento de esgoto de instituiçóes coletivas em zonas suburbanas ou rurais. Entre as contribuiçóes nesse campo, destaque especial deve ser dado às instalaçóes depuradoras do Hospital de Tuberculosos São Luiz Gonzaga e do Asilo de Inválidos do Jaçanã (ambas situadas na região metropolitana de São Paulo), do Leprosário de Santo Ângelo (no município de Mogi das Cruzes) e do Quartel do 70 Batalhão da Força Pública (no município de Sorocaba). (JESUS NETTO, 1940; 1948). Ele também se dedicou ao aperfeiçoamento e melhorias de projetos, assim como à operação de instalaçóes individuais de tratamento e destinação final de esgotos (JESUS NETTO, 1942 b).

Os importantes trabalhos por Jesus Netto desenvolvidos durante toda sua longa carreira profissional possibilitaram avanços significativos das açóes de controle da poluição de águas, contribuindo substancialmente para a melhoria das condiçóes ambientais e de saúde pública no Brasil. Estimular a capacitação de engenheiros e de outros profissionais que se iniciavam nesse novo tipo de atividade foi sempre sua grande preocupação. A concepção das instalações sanitárias que ajudou a empreender e os inúmeros e detalhados artigos que publicou demonstram claramente essa intençâo .

Jesus Netto foi, acima de tudo, um inovador. O ineditismo das tecnologias de controle de poluição de águas e reaproveitamento dos subprodutos do processo de tratamento de esgotos que ajudou a desenvolver e implantar das décadas de 1930 e 1940, algumas delas até hoje pouco utilizadas, colocam-no no restrito grupo dos profissionais que podemos denominar de "visionários".

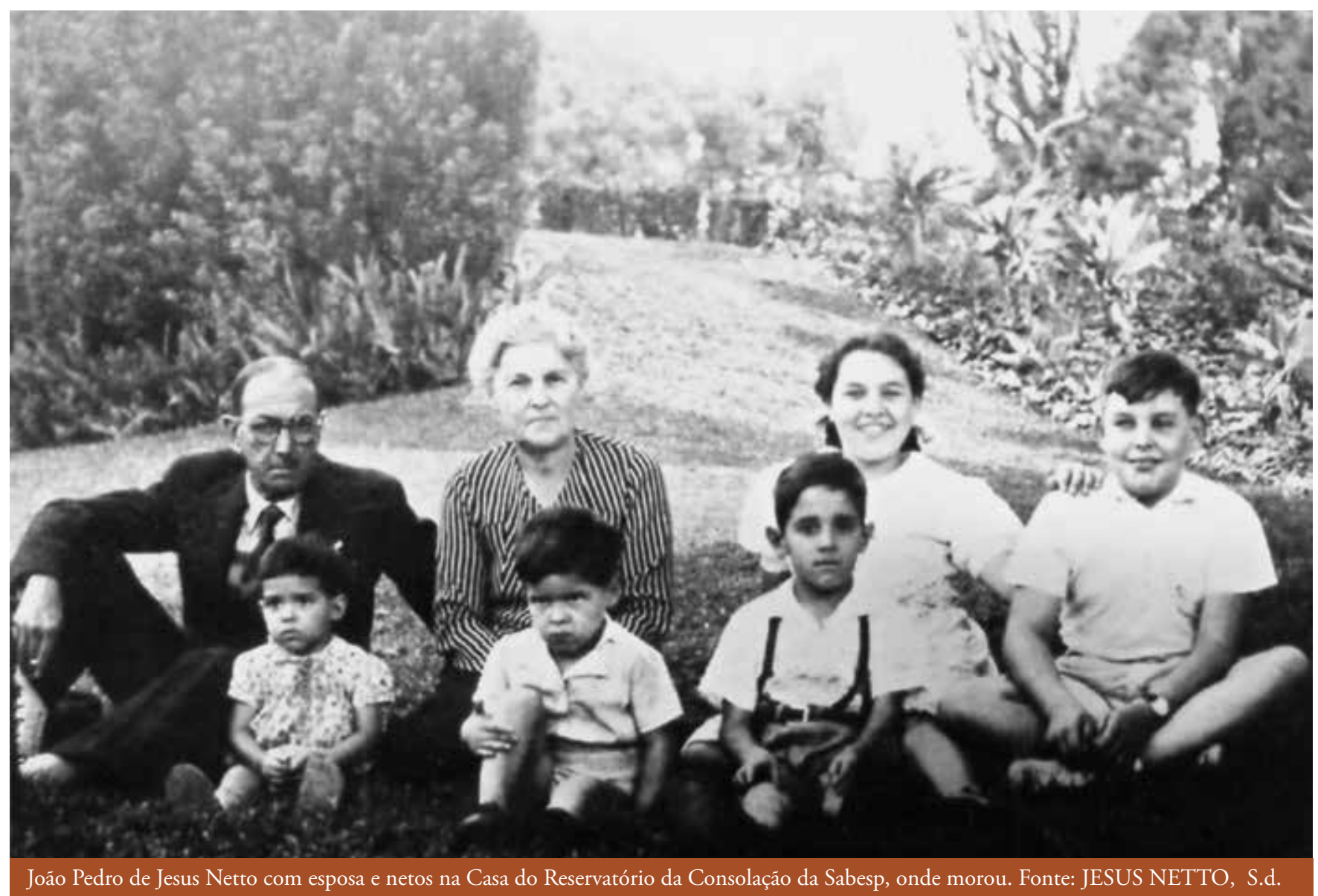




\section{Referências}

A ESTAÇÃO experimental de tratamento de esgotos de Ponte Pequena. Correio de Sáo Paulo, São Paulo, 21 nov. 1934.

AZEVEDO NETTO, J.M. Estação de tratamento de esgotos Jesus Netto. Revista DAE, São Paulo, edição 145, 1986. Disponível em: <http://www.revistadae.com.br/ artigos/artigo_edicao_145_n_168.pdf> Acesso em: 25 mai. 2014.

BOTELHO, Manoel Henrique Campos. Uma vida tratando águas. Memórias do Engenheiro Armando Fonzari Pera. São Paulo: Editora Técnica, 2000. 221 p.

BRITO, Francisco Saturnino Rodrigues de. Melhoramentos do Rio Tietê em Sáo Paulo. Relatório, Seção de Obras do Estado de São Paulo, 1926.

DOS DETRITOS da cidade, São Paulo poderá extrahir dois terços do gaz de que necessita e cem toneladas de adubo por dia. Correio de Sáo Paulo, São Paulo, 8 nov. 1934. JESUS NETTO, João Pedro. Estação experimental de tratamento de esgotos da Ponte Pequena. Boletim do Instituto de Engenharia, São Paulo, v. XVIII, edição no 97, p. 346 a 353, dez. 1935.

JESUS NETTO, João Pedro. Descarga de esgotos nos rios e cursos d'água. Autodepuração. Boletim do Instituto de Engenharia, São Paulo, v. XXII, edição no 118, p. 112 116, 1935.

JESUS NETTO, João Pedro. O gás dos esgotos. Revista RAE, São Paulo, edição no 1, p. 51 - 53, 1936. Disponível em: <http://www.revistadae.com.br/artigos/artigo_edicao_1_n_1322.pdf>. Acesso em: 25 de mai. 2014.

JESUS NETTO, João Pedro. Uma pequena instalação moderna de tratamento de esgotos: Ipiranga. Revista RAE, São Paulo, edição no 2, p. 162-176, 1937. Disponível em: < http://www.revistadae.com.br/artigos/artigo_edicao_14_n_1065.pdf >. Acesso em: 25 mai. 2014.

JESUS NETTO, João Pedro. Contribuição para o estudo da poluição dos cursos d'água. Revista RAE, São Paulo, edição no 4, p. 18-41, 1938. Disponível em: <http://www.revistadae.com.br/artigos/artigo_edicao_4_n_1353.pdf>. Acesso em: 25 mai. 2014.

JESUS NETTO, João Pedro. Contribuição para o estudo da poluição dos cursos d'água. Revista RAE, São Paulo, edição no 6, p. 90 - 116, 1939. Disponível em: <http://www.revis- tadae.com.br/artigos/artigo_edicao_6_n_1368.pdf> Acesso em: 25 mai. 2014.

JESUS NETTO, João Pedro. Três instalações de tratamento de esgotos de pequenas coletividades. Revista RAE, Paulo, edição no 09, p. 16- 31, 1940. Disponível em: <http:// www.revistadae.com.br/artigos/artigo_edicao_9_n_1378. pdf> Acesso em: 25 mai. 2014.

JESUS NETTO, João Pedro. Estação de tratamento de esgotos do Ipiranga; Instalaçáo Experimental de lodos ativados. Revista RAE, São Paulo, edição no 14, p. 22 a 30, 1942 a. Disponível em: <http://www.revistadae.com.br/artigos/artigo_edicao_14_n_1378.pdf> Acesso em: 25 mai. 2014.

JESUS NETTO, João Pedro. Algumas considerações sobre a provisão de águas e esgotos das habitaçóes suburbanas e rurais. Revista do Arquivo Municipal, São Paulo, v. 82, p. 299 - 305, 1942b.

JESUS NETTO, João Pedro. Dados sumários sobre os esgotos da cidade de São Paulo e estaçáo experimental de tratamento de esgotos do Ipiranga. Revista RAE, São Paulo, edição no 17, p. 100 - 115, 1946. Disponível em: < http://www.revistadae.com.br/artigos/artigo_ edicao_14_n_1078.pdf> Acesso em:. 25 mai. 2014.

JESUS NETTO, João Pedro. Instalaçóes de tratamento de esgotos de pequenas coletividades institucionais em São Paulo - Brasil. Revista RAE, São Paulo, edição no 20, p. 14 - 23, 1948. Disponível em: < http://www.revistadae. com.br/artigos/artigo_edicao_20_n_1094.pdf> Acesso em: 25 de mai. 2014.

MACHADO, Aníbal. Valor fertilizante do lodo dos esgotos. O Estado de S. Paulo. São Paulo, p. 2, 20 abr. 1954 (a). MACHADO, Aníbal. Valor fertilizante do lodo dos esgotos. O Estado de S. Paulo. São Paulo, 24 abr. 1954 (b).

OSEKI, Jorge Hajime, 1992. Pensar e viver a construção da cidade. Tese de doutorado, FAUUSP- Faculdade de Arquitetura e Urbanismo da Universidade de São Paulo, SP.

O PROBLEMA do escoamento dos esgotos vae ser encarado de forma a que, no Rio Tietê, não surja uma verdadeira calamidade pública. Correio de Sáo Paulo, São Paulo, 1 nov. 1934.

SÃO PAULO (Estado). Decreto no 28.656, de 12 de junho de 1957. Dá denominação à Estação de Tratamento de Esgotos do Ipiranga do Departamento de Águas e Esgotos. Revista DAE, São Paulo, edição n³0, (1958). Disponível em: <http://www.revistadae.com.br/artigos/artigo_edicao_ no 30_.pdf> Acesso em: 25 mai. 2014. 